\title{
A note on movements of southern right whales between the sub-Antarctic Auckland and Campbell Islands, New Zealand
}

\author{
Nathalie J. Patenaude ${ }^{\dagger}$, Barbara TodD $^{*}$ and Ramari Stewart ${ }^{+}$ \\ Contact e-mail: n.patenaude@auckland.ac.nz
}

\begin{abstract}
To investigate the interchange of southern right whales between wintering grounds of the New Zealand sub-Antarctic, photographs of 31 individuals from Campbell Island were compared to 217 individuals from the Auckland Islands. Three whales first identified at the Auckland Islands in 1995 or 1996 were found at Campbell Island in 1997. One whale identified at Campbell Island in 1995 was seen later that same winter at the Auckland Islands. This provides the first evidence of both within- and between-year movements of whales between the two New Zealand sub-Antarctic aggregations, suggesting that they are part of one intermingling population.
\end{abstract}

KEYWORDS: SOUTHERN RIGHT WHALE; BREEDING GROUNDS; SUB-ANTARCTIC; MOVEMENTS; PHOTOIDENTIFICATION

\section{INTRODUCTION}

Although once abundant throughout New Zealand waters, there are now only two winter concentrations of southern right whales (Eubalaena australis) in New Zealand waters. Whales have primarily been observed at the Auckland Islands $\left(50^{\circ} 33^{\prime} \mathrm{S}, 1^{\circ} 6^{\circ} 15^{\prime} \mathrm{E}\right.$; Patenaude et al., 1998; Patenaude and Baker, 2001) with a smaller aggregation found 160 n.miles further south at Campbell Island (52 33 'S, $169^{\circ} 09^{\prime}$ E; Stewart and Todd, 2001); see Fig. 1. The relationship between these two habitats is unclear. The only previously reported resighting between islands was of a presumed female sighted in May 1988 at Campbell Island and thought to be resighted at Auckland Islands 1.5 months later (Cawthorn, 1990).

Here we report on a collaborative effort to compare regional photo-identification catalogues collected during field expeditions in 1995 and 1997 at Campbell Island (BT and RS) and in 1995, 1996 and 1997 at the Auckland Islands (NP).

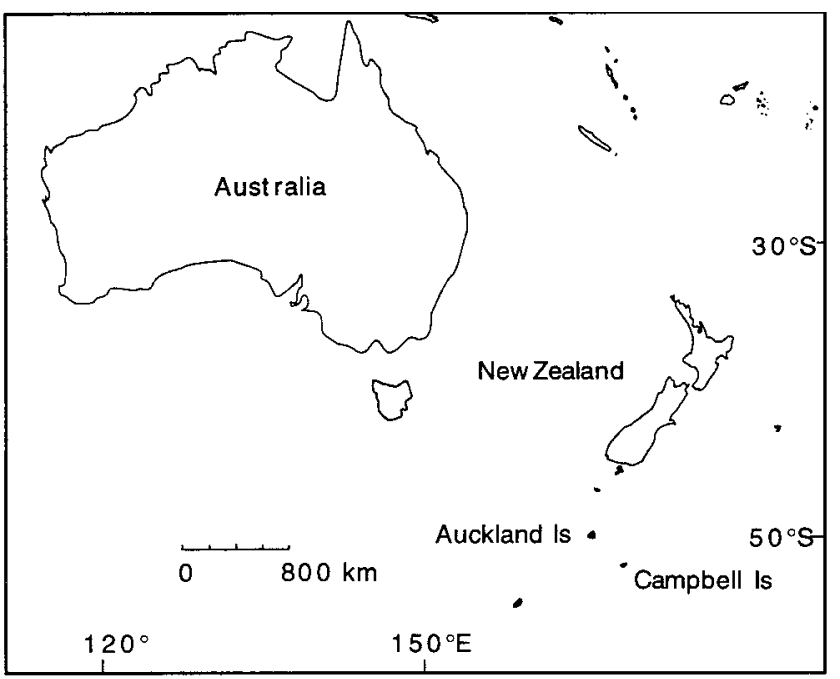

Fig. 1. Location of New Zealand's sub-Antarctic Auckland and Campbell Islands.

\section{METHODS}

Identification photographs were collected in the Auckland Islands during winter field expeditions from mid-July to the first week of August 1995, 1996 and 1997 and in Campbell Island in July 1995 and from late June to late August 1997. Callosity patterns, lip ridges or unusual colour patches were used for individual identification (Payne et al., 1983; Kraus et al., 1986). Photo-identification was conducted from small vessels $(3.8-4.7 \mathrm{~m})$ at both locations, and at times from the deck or mast of a larger motor/sailing vessel (Auckland Islands) or from cliff-tops along Northwest Bay at Campbell Island. Photographs were taken at the Auckland Islands with Kodak Tri-X or T-Max black and white film (ISO 400, pushed to 800 or 1600) or Fuji film (ISO 400 and 1600) and at Campbell Island using 35mm SLR cameras equipped with a range of lenses from $80-500 \mathrm{~mm}$.

Identification photographs at the Auckland Islands were collected non-systematically, except in cases when efforts were directed at capturing cow-calf pairs (Patenaude and Baker, 2001). At Campbell Island, photographs were selectively targeted towards socially active groups. The comparison of photographs between the two regions was limited to the whales' left side. A total of 31 individually identified whales from Campbell Island in $1995(n=5)$ and $1997(n=26)$ were compared to the Auckland Islands catalogue of 217 individually identified whales collected in $1995(n=69), 1996(n=56)$ and $1997(n=92)$. Individually identified whales were compared by two people experienced with photo-identification, and matches were confirmed by a third person experienced with right whale photo-identification. The sex of some photo-identified animals was identified using molecular methods from skin biopsy samples (Patenaude and Baker, 2001).

\section{RESULTS}

Four matches were made between the two regional catalogues (Fig. 2). Of the five whales identified at Campbell Island in 1995, one was sighted at the Auckland Islands later that winter. This whale (ID22, Fig. 2) was first photographed

\footnotetext{
† School of Biological Sciences, University of Auckland, Private Bag 92019, Auckland, New Zealand.

* P.O. Box 24, Kaikoura, New Zealand.

${ }^{+}$P.O. Box 15, Whataroa, South Westland, New Zealand.
} 
Auckland Is.

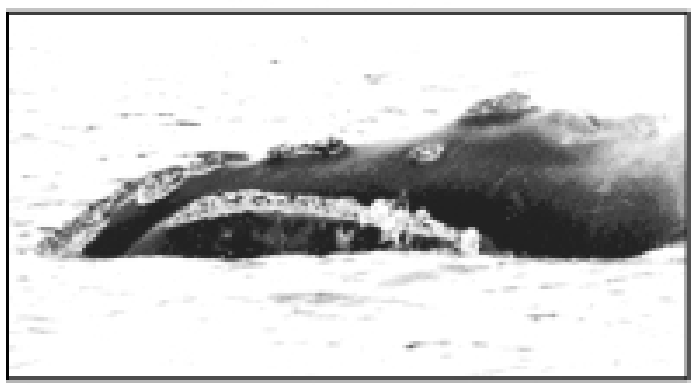

ID22

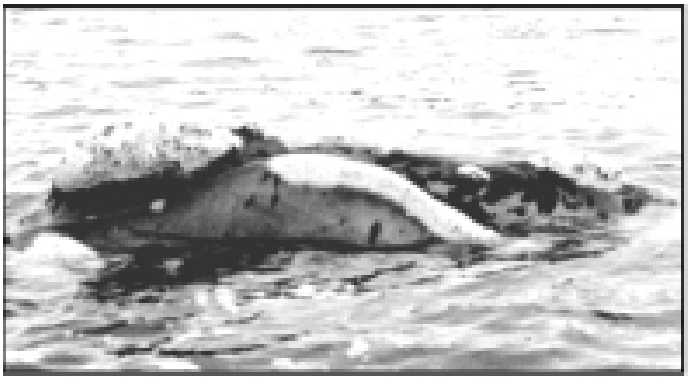

ID43

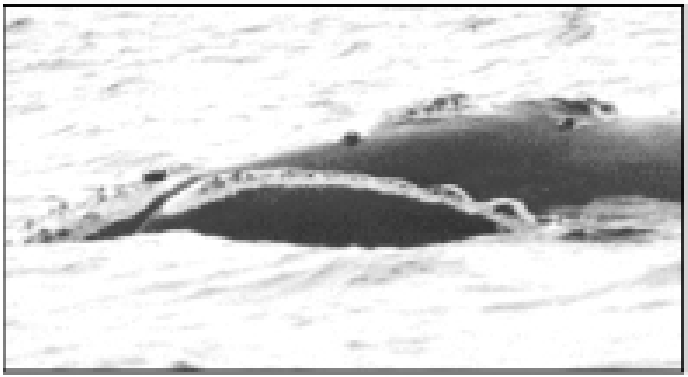

ID62

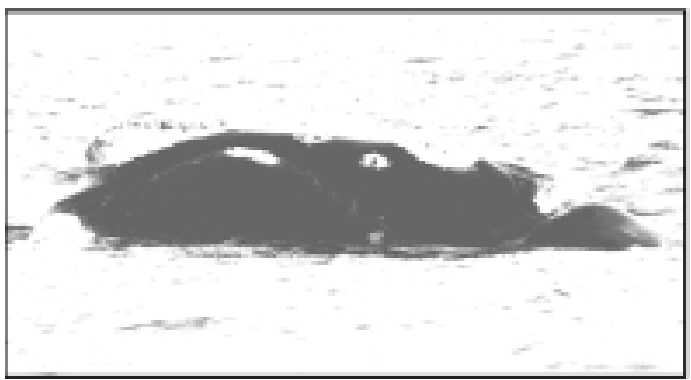

ID70
1 July 1995

25 July 1996

29 July 1996
Campbell is.

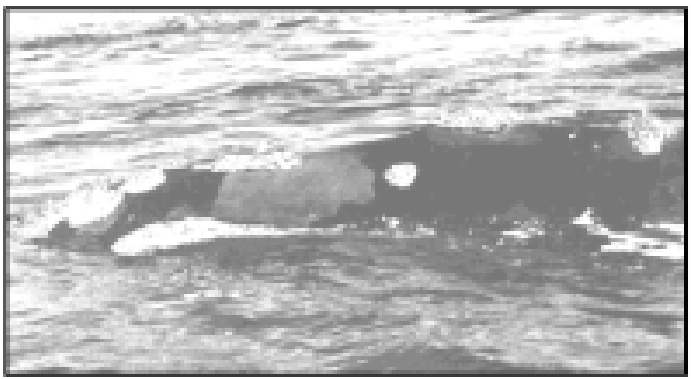

10 July 1995

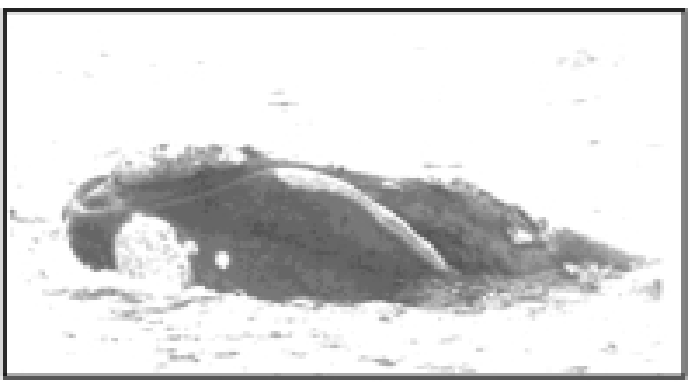

8-24 August 1997

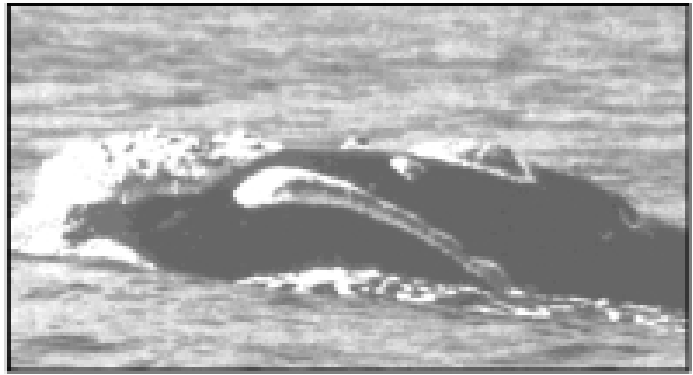

2 August 1997

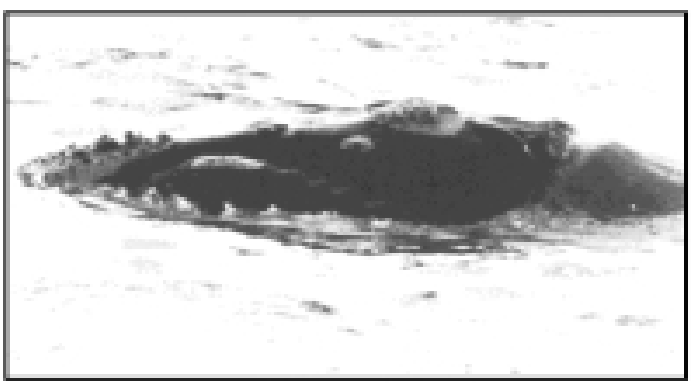

2 August 1997

Fig. 2 Photo-identified southern right whales matched between Auckland Islands (left) and Campbell Island (right).

at Campbell Island on 10 July 1995. It was then photographed at the Auckland Islands 22 days later, in a socially active group.

Of the 26 whales photo-identified at Campbell Island in 1997, three were matched to photographs collected at the Auckland Islands. One whale (ID 43, Fig. 2), identified as a male, was sighted in July 1995 at the Auckland Islands and resighted two years later at Campbell Island on 8, 9 and 24
August 1997. These last three sightings represent the longest within-season residency period recorded for Campbell Island (Stewart and Todd, 2001).

One whale sighted at the Auckland Islands on 25 July 1996 (ID 62, Fig. 2) was resighted on 2 August 1997 at Campbell Island. Another whale sighted on 29 July 1996 at the Auckland Islands (ID 70, Fig. 2) was also resighted 2 August 1997 at Campbell Island. 


\section{CONCLUSIONS}

The photographic evidence provides documented evidence of both within- and between-year movements of whales between the two New Zealand sub-Antarctic aggregations and suggests that the two aggregations are part of one intermingling population. There is insufficient information to conclude if there is age or sex class sub-division between the two regions. However, while almost $12 \%$ of whales sighted at the Auckland Islands in 1995-1997 were calves (Patenaude and Baker, 2001), no cow-calf pairs were sighted at Campbell Island in 1995 or in 1997, although three cow-calf pairs were sighted there in 1983 (Stewart and Todd, 2001).

\section{ACKNOWLEDGEMENTS}

The Auckland Islands southern right whale project was funded by grants from the Whale and Dolphin Conservation Society, the US Department of State (Program for Cooperative US/NZ Antarctic Research), the Auckland University Research Council, Shell/WWF New Zealand and the Percy Sladen Memorial Fund. Logistic support was provided by Southland Conservancy, Department of Conservation. We thank G. Ayburn, M. Brabyn, K. Baird, N. Gales, S. Childerhouse, M. Marx, L. Medrano, B. Yung and L. Broberg for assistance in the field. Thanks also to S. Kafka and the crew of the Evohe for their assistance in the field. Project Tohora was sponsored by The New Zealand Lottery Grants Board, Pacific Development Conservation Trust, Hanimex (Fuji film), Moller Yamaha, Naiad Inflatables, Caltex New Zealand, Ocean Electronics Ltd., Uniden VHF, Spectrum Print, Canon Cameras, Allen Calendars, Okarito Community and the NZ Department of Conservation. S. Baker and R. Constantine provided helpful comments on this manuscript.

\section{REFERENCES}

Cawthorn, M.W. 1990. New Zealand. Progress report on cetacean research, April 1988 to May 1989. Rep. int. Whal. Commn 40:202-5.

Kraus, S.D., Moore, K.E., Price, C.A., Crone, M.J., Watkins, W.A., Winn, H.E. and Prescott, J.H. 1986. The use of photographs to identify individual North Atlantic right whales (Eubalaena glacialis). Rep. int. Whal. Commn (special issue) 10:145-51.

Patenaude, N.J. and Baker, C.S. 2001. Population status and habitat use of southern right whales in the sub-Antarctic Auckland Islands of New Zealand. J. Cetacean Res. Manage. (special issue) 2:111-116.

Patenaude, N.J., Baker, C.S. and Gales, N.J. 1998. Observations of southern right whales on New Zealand's sub-Antarctic wintering grounds. Mar. Mammal Sci. 14(2):350-5.

Payne, R., Brazier, O., Dorsey, E.M., Perkins, J.S., Rowntree, V.J. and Titus, A. 1983. External features in southern right whales (Eubalaena australis) and their use in identifying individuals. pp. 371-445. In: R. Payne (ed.) Communication and Behavior of Whales. AAAS Selected Symposia Series 76. Westview Press, Colorado. xii+643pp.

Stewart, R. and Todd, B. 2001. A note on observations of southern right whales at Campbell Island, New Zealand. J. Cetacean Res. Manage. (special issue) 2:117-120. 